\title{
KONFERENCIA A PEDAGÓGUS-TOVÁBBKÉPZÉS MEGÚJÍTÁSÁÉRT
}

\section{IKER JÁNOS}

a NymE Regionális Pedagógiai Szolgáltató és Kutató Központjának igazgatója

fejlesztes@pszk.nyme.hu

2011. március 8-án a Nemzeti Erőforrás Minisztérium és a Nyugat-magyarországi Egyetem Regionális Pedagógiai Szolgáltató és Kutató Központja konferenciát rendezett a pedagógus-továbbképzés megújításához kapcsolódva.

A konferencia résztvevői: a Nemzeti Erőforrás Minisztérium illetékes vezetői és szakértői, a Rektori Konferencia Pedagógusképző Bizottságának tagjai, a TÁMOP 4.1.2/B projekt keretében létrejött, pedagógusképzést támogató szolgáltató és kutatóközpontok képviselői, a megyékben müködő szakmai szolgáltatók képviselői, egyetemek, szakmai szervezetek vezetői, képviselői.

A konferencia célja: a készülő felsőoktatási és közoktatási törvény koncepciójához kapcsolódva olyan szervezeti és módszertani megújulás előkészítése, amely a pedagógusképzésben és -továbbképzésben épít a nemzeti hagyományokra, szolgálja a kutatási eredményekre épített, modern szemléletủ képzést, továbbképzést, és mindenekfelett gyakorlatközpontú. Egyben elősegíti a pedagógusképző intézmények, a szakmai szolgáltatók, a közoktatási intézmények együttmúködését hálózati keretben, és szakmai javaslatot ad a rendszer megújítására, a pedagógus életpályán átívelő fejlesztésekre; az EU-s pályázati, fejlesztési források hatékony felhasználására.

A szakmai anyagokkal jól előkészített konferencián Faragó Sándor rektor (NymE) megnyitója és Madarász Sándor (NEFMI) köszöntője után a következö előadások hangzottak el:

- A pedagógusképzés és -továbbképzés rendszerének összhangja, a felsőoktatási intézmények szerepe a pedagógus-továbbképzésben (Rádli Katalin, fötanácsos, NEFMI)

- Pedagógusok szakmai fejlődése az európai gondolkodásban (Stéger Csilla, főosztályvezető, Oktatási Hivatal)

- A tanárképzés és a pedagógus-továbbképzés fő jellemzői az elmúlt négy évben (Iker János, igazgató, NymE RPSZK)

- Javaslat a pedagógusképzés rendszerének megújítására és a SINUS-program magyarországi adaptációjára (vizsgálatok, kutatási eredmények bemutatásával) (Iker János, igazgató, NymE RPSZK, Réti Mónika, kutató és Matthias Stadler, a németországi program egyik koordinátora). 
- Thaisz Miklós (NEFMI) a pedagógus életpályamodellt foglalta össze részletes prezentációban, illetve annak kapcsolatát a továbbképzési rendszerrel, amelyet a jelenlévők nyomtatott formában kaptak meg.

Az előadók mindegyike - az adott téma kifejtése mellett - hangsúlyozta a pedagógusképzés, -továbbképzés szakmai egységét, a gyakorlati képzés fontosságát, illetve a kapcsolódást egy olyan kívánatos pedagógus életpályamodellhez, amely a képzést, a bevezető támogatási rendszert és a folyamatos szakmai fejlődést egy koherens rendszerré változtatja.

Az előadásokat követően a kerekasztal felkért hozzászólói: Falus Iván (Tanárképzők Szövetsége), Hauser Zoltán (Rektori Konferencia), Kaposi József (OFI), KöpecziBócz Tamás (KIM), Sándorné Kriszt Éva (Rektori Konferencia), Stéger Csilla (Oktatási Hivatal), Turbók Arnold Bertalan (GyMS M. Pedagógiai Intézet) reflektáltak az előadásokra. A felkért hozzászólók mindegyike fontosnak tartotta a pedagóguspálya presztízsének megerősítését, mind szakmai, mind anyagi tekintetben. A pedagógus életpályamodellhez javasolták, hogy az európai ajánlások alapján a pedagógusok kompetenciáinak fejlesztésében a támogatási aspektus kerüljön a középpontba, és a továbbképzési rendszer is ezt kell, hogy szolgálja elsősorban, és legyen cél a közoktatás minőségének javítása, ellenőrzési rendszer müködtetése.

A résztvevők a SINUS-programról szóló előadáshoz kapcsolódva fontosnak tartották a pedagógus-továbbképzési rendszer megújítását a következő alapelvek mellett:

1. Meg kell erősíteni, hogy a pedagógus-továbbképzések és a kapcsolódó szakmai szolgáltatások állami feladatok, és a müködtetést, a minőséget szigorú állami ellenőrzés és szakmai sztenderdek mellett kell biztosítani.

2. A megyénként (önkormányzati /megyei kormányhivatal/ fenntartású vagy együttmüködési szerződés keretében) müködő szakmai szolgáltató intézmények müködési területükön felelösséget kell, hogy vállaljanak a közoktatás szakmai fejlesztéséhez kapcsolódó szakmai szolgáltatások és az oktatásirányítás szakmapolitikai döntéseinek színvonalas megvalósításáért.

3. A pedagógus-továbbképzésekben az eddiginél hatékonyabb módon kell együttmüködni a pedagógusképzés mühelyeivel (egyetemek, föiskolák) a szolgáltatások, a kutatások és az eredmények hasznosítása területén.

4. Építeni kell a mentorálással segített tanári öntevékenységre, a pedagógus teamek munkájára, és ki kell alakítani - szakmai koordináció mellett - a jó gyakorlatok közvetítésének, disszeminációjának hálózati kereteit a német SINUS-program hazai adaptációjával.

A SINUS-programot a '90-es évék végétől fokozatosan fejlesztették ki Németországban, először egy 150 iskolából álló hálózaton, majd a második hullámban 850 , a harmadik hullámban 1850 iskola vett részt, és 2007-től a tartományokban az öszszes iskola bevonása folyik.

A SINUS-módszer kulcseleme, hogy a részt vevő pedagógusok a képzés során szorosan együttmüködnek, majd a későbbiekben kollaboratív hálózatot alakítanak ki. 
A tudásmenedzsmenttel kapcsolatos szakirodalom egyértelmüen támogatja az ilyen kollaboratív tudásépítő hálózatok kialakítását és a szociális média hasonló kísérletei, illetve a Web 2.0 alkalmazások sikere is arra utal, hogy az ilyen hálózatok óriási szinergiát képesek létrehozni. Ahhoz azonban, hogy müködő tudásépítő és -megosztó hálózat alakuljon ki, fontos megismernünk a tanári együttmüködés jelenlegi hazai kultúráját. Ehhez - a SINUS-program rövid bemutatása mellett - hatvanöt iskolából 2000 pedagógus bevonásával vizsgálatot végzett a NymE Regionális Pedagógiai Szolgáltató és Kutató Központ. Ennek célja volt, hogy a rendkívül összetett SINUSrendszer alapjául szolgáló tanári viselkedésminták elfogadását, a képzés felépítését, a tanári támogató hálózat kiépítését hazai kontextusban értelmezzük, illetve a tanári együttműködést, közös gondolkodást segítő módszerekkel kapcsolatos (szociokulturális, nemzeti különbségekből, illetve a hazai oktatási rendszer sajátosságaiból adódó) jellegzetes attitüdöket feltárjuk. Vizsgálataink arra utalnak, hogy a kreatív, alkotó gondolkodású pedagógusok többsége (akik válaszaik nyomán háromnál több forrásból készülnek tanítási óráikra - a teljes mintából 37\% -, gyakran konzultálnak virtuális platformokon, alkalmaznak saját készítésü tananyagokat) szívesen osztaná meg tapasztalatait (a 37\%-ból 87\%). A teljes mintában a jó gyakorlatok megosztását elutasítók aránya ennél alacsonyabb, $23 \%$ volt. A jó gyakorlatok megosztását visszautasítók elsősorban a 10-20 év közötti gyakorlattal rendelkező, gimnáziumi tanárok közül kerültek ki. A jó gyakorlatok megosztása felmérésünk alapján egyértelmü összefüggést mutat az alábbi tényezőkkel:

- a továbbképzésre (önképzésre) szánt idő;

- a felkészüléshez használt források sokfélesége, változatossága;

- a nevelötestület tagjaival folytatott konzultáció gyakorisága és típusa;

- az önálló feladatalkotás.

Érdekes ugyanakkor, hogy a jó gyakorlatok megosztását elutasító pedagógusok is egyöntetüen kíváncsiak kollégáik jó gyakorlataira: a válaszadók 98\%-a szerint inspiráló mások jó gyakorlatainak megismerése, még a más szakos kollégák esetében is.

A munkaközösségek többsége azonban nem müködik alkotó mühelyként (a munkaközösségi feladatbankkal kapcsolatban alig kaptunk pozitív válaszokat, a válaszadók 70\%-a említi a problémák között az elszigeteltséget, a segítő együttmüködés hiányát.

A kollegiális együttmüködés jellemzően a napi problémákra, egyes gyakorlati kérdések gyors megoldására fókuszál - ritka a pedagógiai, módszertani kérésekkel kapcsolatos tapasztalatcsere. Bár a válaszadók mintegy kétharmada konzultál rendszeresen más szakos kollégákkal is, az iskolák közötti együttmüködés tanár-tanár interakciókban alig $10 \%$, és a napi rendszerességgel konzultálók aránya is csupán mintegy $50 \%$. Ez azt is jelenti, hogy a tanárok mintegy fele legfeljebb heti rendszerességgel, 5\%-uk egyáltalán nem konzultál kollegáival.

A fentiek alapján úgy véljük, hogy az alkotó gondolkodás erősítése, támogatása, és a más szakos kollégákkal való együttmüködés segítése alapvetően javíthatja a tanári 
hatékonyságot, és csökkenti az elszigeteltség nyomán kialakuló kiégés veszélyét. A SINUS-módszer alapvetően alkalmas ezen tanári kompetenciák megerösítésére.

Bár a problémák között az együttmüködés szorosabbra fonása ritkábban szerepelt, a SINUS-módszerrel kapcsolatos várakozások között a válaszadók mintegy fele említette a tanári együttmüködés fontosságát.

A résztvevők a vita után elfogadták azt a szakmai javaslatot, hogy a SINUSprogram magyarországi adaptációja hasznos lenne a hazai pedagógusképzési rendszer megújításához. A továbbképzéssel kapcsolatos pályázatokhoz az alábbi szakmai specifikációkat tartották fontosnak:

- A készülő törvények koncepciójához (felsőoktatási, közoktatási, életpályamodell) és az európai uniós dokumentumokhoz kapcsolódva a pedagógus-továbbképzéshez kapcsolódó alapvető pályázatban a pedagógusképző felsőoktatási intézményekben határozódjék meg a pályázók köre oly módon, hogy azok kötelesek legyenek együttmüködni közoktatási szakmai szolgáltatókkal és közoktatási partnerintézményekkel, vagy maguk alakítsanak komplex szolgáltató és kutatóközpontokat a továbbképzés koordinálására. Ezeket célszerü regionális szinten értelmezni.

Ez azért is fontos, mert az európai uniós dokumentumokban terminológiailag három összefüggő dolog van: 1 . ITE (initial teacher education=tanárképzés), 2. induction (=bevezető támogatási rendszer, ami csak részben egyezik a mi gyakornoki rendszerünkkel) és 3. CPD (continuous professional development=nálunk ez a tanártovábbképzés, ami persze nem egészen ugyanaz. Az egész tulajdonképpen egy életpálya kontinuumba helyezödik. Ezt a rendszert kell hosszú távon megcélozni, és hozzá szervezeti rendszert kialakítani.

- A továbbképzési rendszer kulcseleme lenne, hogy egy-egy pedagógusképző felsőoktatási intézmény (vagy az egyetemhez kapcsolódó szolgáltató és kutatóközpont) szakmai koordinációjával a részt vevő pedagógusok, intézmények önkéntes jelentkezés alapján működjenek együtt, majd később egy kollaboratív hálózatot alakítsanak ki. Ezeket a tudásmenedzsmenttel kapcsolatos szakirodalom, a programmal kapcsolatos hazai kutatási eredmények alapján kell létrehozni. Ahhoz azonban, hogy egy müködő tudásépítő és -megosztó hálózat kialakuljon, fontos lenne még általánosabban megismerni a tanári együttmüködés jelenlegi hazai kultúráját. Erre vonatkozólag a Nyugat-magyarországi Egyetem Regionális Pedagógiai Szolgáltató és Kutató Központjának vannak régióra szóló eredményei, de ezt a bevezetés szakmai előkészítésére, az érdeklődés felkeltésére országos, reprezentatív kutatással kellene megerősíteni. Erre is célszerü lenne pályázatot kiírni.

- A pedagógus-továbbképzési rendszer meghatározó pályázata a SINUSmodell hazai adaptációját segítse oly módon, hogy (a kutatási eredmények alapján) a tanári együttmüködés formáiban és módszereiben négy 
modellt segítsen bevezetni az alábbi tartalommal és szakmai kulcsterületek szerint:

\begin{tabular}{|c|c|c|c|}
\hline \multicolumn{2}{|r|}{ modul } & \multirow[b]{2}{*}{$\begin{array}{l}\text { tartalom } \\
\text { - } \text { az egyes feladattípusok } \\
\text { jelentősége; } \\
\text { - a feladatok tervezése, } \\
\text { kivitelezése; } \\
\text { - a tanulási környezet } \\
\text { diverzitásának tervezése; } \\
\text { - nyílt végű feladatok } \\
\text { kezelése; }\end{array}$} & \multirow[b]{2}{*}{\begin{tabular}{l}
\multicolumn{1}{c}{ kulcsterületek } \\
feladatok a tanítás napi \\
gyakorlatában - kérdés- és \\
problémafelvetés; motiváció, \\
kompetenciafejlesztés \\
és a tanulók önbizalmának \\
erősítése; fejlesztő feladatok \\
szerepe; az egyes \\
feladattípusok alkalmazása
\end{tabular}} \\
\hline 1. & $\begin{array}{l}\text { A feladatkultúra } \\
\text { továbbfejlesztése }\end{array}$ & & \\
\hline 2. & $\begin{array}{l}\text { Természettudomá- } \\
\text { nyos vizsgálódás } \\
\text { és kisérletek }\end{array}$ & $\begin{array}{l}\text { - a kísérletek céljának } \\
\text { újraértelmezése; } \\
\text { - a tanulók segítés } \\
\text { a természettudományos } \\
\text { vizsgálódásban; } \\
\text { - kutatás alapú tanulás } \\
\text { hétköznapi tapasztalatok } \\
\text { értelmezése; } \\
\text { - természettudományos } \\
\text { gondolkodásmód a tanítási } \\
\text { órákon; }\end{array}$ & $\begin{array}{l}\text { kísérletezés, adatgyüjtés, } \\
\text { összehasonlítás, modellezés, } \\
\text { megfigyelés, reflexió szerepe; } \\
\text { az inquiry based tanulás } \\
\text { alapvető lépései: tervezés } \\
\text { és koncepció, implementáció, } \\
\text { elemzés és interpretáció, } \\
\text { alkalmazás és prezentáció } \\
\text { szakaszai }\end{array}$ \\
\hline 3. & A hibákból tanulni & $\begin{array}{l}\text { - típushibák és tévképzetek } \\
\text { felhasználása a tanítás } \\
\text { folyamatában> } \\
\text { - a tanulói hibák } \\
\text { feldolgozásának konstruktív } \\
\text { módjai; } \\
\text { - a hibák, mint tanulási } \\
\text { lehetőségek - a mögöttes } \\
\text { koncepciók láttatása; }\end{array}$ & $\begin{array}{l}\text { a hibák és tévképzetek } \\
\text { konstruktivista megközelítése; } \\
\text { értékelés és fejlesztés; } \\
\text { a hibákkal kapcsolatos } \\
\text { általános attitüdformálás } \\
\text { (a hibák, mint lehetőségek } \\
\text { és nem, mint lezárt kudarcok); } \\
\text { a tanár segítő, támogató } \\
\text { szerepének fejlesztése }\end{array}$ \\
\hline 4. & $\begin{array}{l}\text { Értékelés - } \\
\text { a kompetenciák } \\
\text { felmérése, } \\
\text { a kompetenciákkal } \\
\text { kapcsolatos } \\
\text { visszajelzések }\end{array}$ & $\begin{array}{l}\text { - az újszerü feladatkultúrához } \\
\text { tartozó értékelési-mérési } \\
\text { rendszerek; } \\
\text { - a tanórai és egyéb } \\
\text { értékelések; } \\
\text { - visszajelzés a tanulási } \\
\text { folyamatról és az } \\
\text { eredményekről. }\end{array}$ & $\begin{array}{l}\text { nyílt végü feladatok } \\
\text { alkalmazása; az értékelési } \\
\text { típusok használata; } \\
\text { az átláthatóság, objektivitás } \\
\text { és motiváció kérdései; } \\
\text { a tanulók támogatása } \\
\text { a mérés-értékelés segítségével. }\end{array}$ \\
\hline
\end{tabular}


- Célszerü lenne a pályázók körét a statisztikus régiókhoz (6), illetve a központi régióhoz (ott 2) kötni, és előnyben részesíteni azokat a felsőoktatási intézményeket, ahol az együttmüködés során a pedagógusképzést és a közoktatást segítő szolgáltató és kutatóközpontok már létrejöttek.

- A források a hálózat kialakítását, a modellekben meghatározott tartalom és kulcspontok szerinti továbbképzési rendszer kialakítását szolgálnák oly módon, hogy a támogatási összeg 70\%-a az intézményeket, a jó gyakorlatok rendszerében szerepet vállaló pedagógusokat és a közremúködő szakmai szolgáltatókat támogatná a munka arányában, és 30\% biztosítaná a felsőoktatási intézmény/központ által a hálózati rendszer müködését.

- A projekt végére olyan modellnek kell kialakulni és a fenntartási időszakban müködtetni, amely megerősíti, hogy a pedagógus-továbbképzések és a kapcsolódó szakmai szolgáltatások állami feladatok, és a müködtetést, a minőséget szigorú állami ellenőrzés (erre is lehetne projektet kiírni, minősítendő a központok, hálózatok fejlesztő munkáját) és szakmai sztenderdek mellett kell biztosítani. El kell érni, hogy a szakmai fejlesztések, kutatási eredmények viszonylag gyorsan és hatékonyan kerüljenek hasznosításra a közoktatás területén.

- A fentiekhez kapcsolódva a megvalósításban feltétlenül figyelembe kell venni, hogy a közoktatásban és a pedagógusképzésben olyan módszertani megújulásra van szükség, amely épít a jó szakmai hagyományokra, szolgálja a kutatási eredményekre épített, modern szemléletủ képzést, továbbképzést, és mindenek felett gyakorlatközpontú. Ehhez nélkülözhetetlen a pedagógusképző intézmények, a szakmai szolgáltatók és a közoktatási intézmények együttmüködését segítő hálózati szervezet kialakítása és folyamatos müködtetése.

- Az egész továbbképzési rendszer támogasson egy olyan pedagógus életpályamodellt, amely a képzést, a bevezető támogatási rendszert és a folyamatos a szakmai fejlődést egy koherens rendszerré változtatja. Ennek nyomán a tanárok:

- a felsőoktatási intézményben szerzett olyan képesítéssel rendelkezzenek, amely megfelelő egyensúlyt teremt a kutatás alapú tanulmányok és a tanítási gyakorlat között,

- tantárgyaik területén magas szintü szaktudással, valamint megfelelő pedagógiai-módszertani kompetenciákkal rendelkezzenek,

- pályájuk kezdetén hatékony támogatási programokon vehessenek részt,

- pályafutásuk alatt megfelelő mentori támogatásban részesüljenek, egész pályafutásuk alatt ösztönzésben, támogatásban részesüljenek, hogy formális és informális tanulás keretében új tudásra, készségekre, kompetenciákra tegyenek szert, beleértve a csereprogramok lehetőségeit is. 